\title{
Defining Moments in Policy Development, Direction, and Implementation in Irish Initial Teacher Education Policy
}

Teresa O'Doherty ${ }^{1}$

$\approx$ This paper explores the impact of significant OECD documents on the development of Irish education policy, specifically teacher education policy, over the last half century. While other commentators have argued that Irish education has been predominantly influenced by policy developments in the UK, US or Europe, this paper identifies the OECD as a significant trigger for domestic policy reform and discusses key reports/publications that have influenced both ideological and structural reforms of Irish education. Long before the growth of evidence-based reform or the emergence of a global education policy field, Irish policy makers invited the newly formed OECD to review Ireland's provision of education; this review generated base-line data and highlighted both the inequity of Irish education as well as its inadequacy in providing for the future needs of the Irish economy. Thus began a long-term relationship with the OECD, which has served to prompt and guide policy revision and reform at critical decision points over five decades. While engagement with the OECD cannot simply explain changes in Irish education, it does, however, provide a valuable perspective on domestic policy making.

Keywords: gifted education, talent support, Germany, federal states, foundations, associations, enrichment, acceleration

$1 \quad$ Faculty of Education, Mary Immaculate College, Limerick, Ireland; teresa.odoherty@mic.ul.ie 


\section{Opredelitev mejnikov v razvoju, usmerjenosti in v implementaciji politik na področju izobraževanja učiteljev na Irskem}

Teresa O’DOHERTy

$\approx$ V prispevku so analizirani vplivi pomembnejših dokumentov OECD na razvoj irske izobraževalne politike, še posebej na izobraževanje učiteljev, v zadnje pol stoletja. Medtem ko drugi menijo, da je bilo izobraževanja na Irskem predvsem pod vplivom razvoja politikv Veliki Britaniji, Združenih državah Amerike ali Evrope, prispevek identificira OECD kot pomemben vzvod za nacionalne zakonodajne reforme; razpravlja o ključnih poročilih/publikacijah, ki so vplivali/-e na ideološke in tudi strukturne reforme izobraževanja na Irskem. Veliko pred razmahom reform, osnovanih na raziskavah, ali pojavom globalnega polja izobraževalnih politik so irski politiki povabili novo oblikovani OECD k pregledu izobraževanja na Irskem. Ta je vključeval generalizirane podatke, med ugotovitvami pa sta bila poudarjena neenakost $\mathrm{v}$ izobraževanju in neprimernost za zadovoljevanje potreb irskega gospodarstva v prihodnje. Tako se je začelo dolgoročno sodelovanje z OECD, ki je omogočalo sprotno posodabljanje zakonodaje in nudilo smernice pri reformah v kritičnih točkah odločanja zadnjih pet desetletij. Pregled sodelovanja z OECD sicer ne more nuditi razlage sprememb izobraževanja na Irskem, lahko pa ponudi pomembno perspektivo na nacionalno nastanjanje nacionalne politike.

Ključne besede: $\mathrm{OECD}$, politike na področju izobraževanja učiteljev, reforme, Irska 


\section{Introduction}

Teacher education policy Ireland, as in all European states, has been shaped by the historical, political, economic, cultural, religious and linguistic characteristics of the nation (Coolahan, 2001). The extent to which developments in any education system are the subject of policy borrowing, transfer, and copying, is an enduring debate. David Limond (2010) in his paper "[An] historic culture ... rapidly, universally, and thoroughly restored? British influence on Irish education since 1922", has suggested that "a post-colonial overhang affects Irish policy-makers and bureaucrats in their educational policies and practices". It is Limond's thesis that Irish education has been more influenced by developments in Britain than elsewhere in Europe and that, "A selfsatisfied patriotism or "banal nationalism" remains the common currency of Irish political and social discourse, making it difficult or even impossible for politicians, or policy-makers of any kind, to concede that Ireland has anything to learn from anywhere else - least of all from Britain". O’Donoghue and Harford (2012) robustly contest Limond's theory on British influence in Irish education since 1922. In their response, they illustrate comprehensively that European, and possibly American, influences have greater on contemporary Irish educational developments than those of the nation's nearest neighbour. Both papers provide a useful springboard for a discussion on the nature of influences on Irish policy and practice; acknowledging the complex interplay of global reform forces on Irish education, which has been developed by others (Conway, 2013; Conway \& Murphy, 2013), this paper examines the history of Irish education's engagement with the supranational institution, the OECD. It is uncontested that the decision to invite the OECD to undertake a statistical review of Irish education in the 1960 s fundamentally reshaped the nature and purpose of education (O'Sullivan, 2005). What is less clear is how this early engagement with the OECD, which pre-dated the global education reform movement (Sahlberg, 2011) and the associated benchmarking of education systems, has continued to shape and guide domestic policy in later decades. Acknowledging that "context and history matter deeply and cannot be borrowed" (Sellar \& Lingard, 2013, p. 722), this long-frame review examines the impact of significant OECD documents from 1965, 1991, 2005 and 2009 on the evolution of Irish education policy, specifically teacher education policy. To what extent did Irish policy makers depend on external reviews and guidance to spur policy development and reform? Was the repeated intervention of the OECD required to legitimize policy development by the state in education and particularly teacher education, which was provided by the churches? 
This paper establishes the nature of teacher education in the decades before the publication of the Investment in Education Report (OECD, 1965), and thereafter chronologically examines the impetus provided by OECD documents in subsequent decades, to domestic education policy development.

\section{The origins and development of teacher education in Ireland}

A popular commitment to and interest in education was well established before the state gave support to schooling in Ireland through the establishment of the National School System in 1831. The educational census of 1824 recorded that there were over 9,000 schools in existence, catering for two out of every five children of school going age at the time. (Coolahan, 2011b). Formal teacher education was also established in advance of state intervention; in 1811, the Kildare Place Society (KPS), a voluntary organization committed to the education of the poor, initiated its first programme of teacher training (Hyland \& Milne, 1987) and the first state grants for teacher education were provided to the KPS in 1815. After 1831, the government-appointed Commissioners of Education provided for teacher education at their premises in Marlborough Street. Within the framework of the United Kingdom, the system of education promoted cultural assimilation and socialization, and control over teacher education, curricula and textbooks enabled the systematic erosion of the Irish language and culture while normalizing the values and traditions of the imperial power (Harford, 2008, p. 76). The Commissioners provided programmes on a "mixed education (religious) principle" but as the concept of a schooled society grew during the nineteenth century, the Catholic Church became "intimately involved" in the development of the national school system, and viewed teacher training as an area over which it wished to exercise control (O'Donoghue, 2006, p. 7). In 1884, following much agitation, the state agreed to finance denominational training colleges; this decision represented in many respects a defeat of the core principle non-denominational provision within the national system of education (Harford, 2009, p. 56). The teacher education programme was extended to two years and by the turn of the century approximately 50\% of primary level teachers were formally trained (Coolahan, 1981, p. 32).

Following Independence in 1922, the structure of Irish education was characterized by a high level of continuity in which the ownership and management of schools were retained by the religious denominations, while the state concentrated on curricular change. Five denominational colleges (four Roman Catholic and one Church of Ireland) offered a two-year teacher education 
programme. Just as teacher education was viewed as a tool for cultural assimilation during the nineteenth century (Harford, 2010), it was valued post-1922 as a mechanism of the state to secure the revival of Gaeilge (Irish) as a living language, thus underpinning the cultural identity of the nation. For the first four decades of the new state, the promotion of the Irish language was prioritized within teacher training colleges; the language of instruction and all social interaction was in the medium of Irish. The emphasis on the Irish language was reinforced by the inspectorate who controlled the content of the programme, set and corrected examinations, and inspected the lecturers (Coolahan, 2013, p. 11). While the state financed teacher education and regulated the content and curriculum, the churches provided teacher education in single-sex residential colleges where students were carefully supervized.

University provision of teacher education for secondary teachers was established in 1912. Rooted within classical humanism, the Higher Diploma in Education was a one-year postgraduate programme. Trinity College created the first chair of Education in 1905, while the constituent colleges of the National University appointed professors of education during the subsequent decade. The Registration Council for post-primary teachers was established in 1918; however, registration was not a pre-requisite for appointment to a teaching position and given that many of the teachers were members of denominational congregations, for many decades almost 50\% of secondary teachers were unregistered.

Throughout the first half of the twentieth century, the infrastructure of university teacher education provision remained underdeveloped and in 1967 the Report of the Commission on Higher Education recorded that while the four large universities had 722 Higher Diploma students, they had a total of 14 fulltime academic staff, only four of whom were above junior lecturer status (Coolahan, 2004, pp. 6-7). Few students undertook master's degrees in education, and very little research was published.

\section{Investment in Education Report 1965 - the key to re- shaping Irish education}

Following independence, Ireland was "more concerned with the preservation of the past than with the future" (O'Connor, 2014, p. 197), and by the 1960 s Ireland was in a "disastrous economic situation"; protectionist economic policies had failed, creating a large balance of payments deficit, and the country had lost 400,000 people though emigration between 1951 and 1961 (Loxley et al., 2014, pp. 174-175). Evidence of a new direction in economic planning was apparent in 
T.K. Whitaker's Economic Development, published in 1958, further expounded upon in the Programme for Economic Expansion, published later in the same year. Ireland's attendance at the 1961 Washington Conference (O’Sullivan, 2005, $135 \mathrm{ff}$ ) changed the course of Irish education and by 1963, education and "human investment" were tightly coupled; "Since our wealth lies ultimately in our people, the aim of educational policy must be to enable all individuals to realize their full potential as human persons" (Second programme for economic expansion, p. 13, cited by O'Sullivan, 2005, p. 135). Within a global discourse in which education and human capital production were inextricably linked, acceptance of the role of education in the salvation of the economy required a paradigmatic shift on the part of Irish politicians and educationists alike.

The decision to participate in the "Investment in Education" project under the auspices of the then recently formed OECD, was to bring the deficiencies and gross inequalities of the Irish system to "unprecedented international scrutiny" (Walsh et al., 2014, p. 119); it also represented a move by the state in "elbowing the churches to one side and committing itself to provide proper resources from the public purse" (Farrell, 1998, p. x). The baseline data that the audit generated highlighted the inadequacy of system to meet the needs of a modern society and served to shift the domestic policy from one of cultural nationalism to one that prioritized human capital production; the capacity of schooling to contribute to economic development became the driving purpose of education during the following decades (O’Sullivan, 2005)

While first and second level education experienced expansion and radical reform in the decades that followed, the decade from 1965 to 1975 also was the last period of fundamental revision in teacher education (Coolahan, 2007). The Investment in Education Report was followed by the Commission on Higher Education Report (1967), and the Higher Education Authority (HEA) Report on Teacher Education (1970). As a consequence teacher education courses were revized: programmes for primary teachers were restructured and extended, and the colleges assumed greater independence from the Department of Education. Staff numbers increased, libraries were improved, and colleges became co-educational, with the requirement for student residence ceasing. Colleges became affiliated with universities, and the introduction of the three-year BEd degree programme in 1974 ensured that teaching became an all-graduate teaching profession (Coolahan, 2007, p. 3). The study of the Foundation Disciplines (philosophy, sociology, history and psychology of education), pedagogy of curricular areas, and "Teaching Practice" formed the core of the programme, while students also studied an "academic subject". The programmes were subject to the normal quality assurance processes associated with their affiliated university, 
and the Inspectorate of the Department of Education annually examined 10\% of final year students on Teaching Practice. While the concurrent programme was the major route into primary teaching, a consecutive postgraduate programme was introduced at various times when a shortage of primary teachers occurred.

A binary approach to second level teacher education developed in the 1970s, reflecting the academic/ vocational dichotomy (Gleeson, 2004, p. 49). The Higher Diploma became a full-time postgraduate programme, catering for the "academic" subjects. The education departments of the universities were expanded, new professors were appointed and more fulltime staff employed. New master's programmes and research associations were developed: the Reading Association of Ireland (1975) and the Educational Studies Association of Ireland in 1976. Although incremental adaptations were made by individual institutions to the content and approach of the Higher Diploma, it remained a one-year programme for more than 100 years, until September 2014 (Coolahan, 2013, p. 10). Prompted by the HEA Report on Teacher Education (1970), the provision of concurrent teacher education programmes for specialist second-level teachers expanded significantly during the 1970s; Thomond College of Education, Limerick was established in 1971, specializing in preparing teachers for physical education and vocational areas such as materials technology (wood), engineering, and science education. The National College of Art and Design, which offered art education programmes became more autonomous, and the specialist colleges for home economics in Sligo and Dublin became associated with universities. The provision of concurrent teacher education programmes has increased, and $32 \%(n=464)$ of all second level teachers qualified in 2011 came through concurrent programmes (Hyland, 2012, p. 12).

\section{OECD 1991 Review - a landmark in the development of policy in Irish education}

Although the OECD was initially invited to examine teacher education at the end of the 1980s, its report, Review of National Education Policies: Ireland (1991) was far more expansive than anticipated (Galvin, 2009, p. 277). Affirming the quality and provision of teacher education, it stated:

We visited nearly all the initial education institutions and were impressed with the quality and commitment of their staffs, the strength of the programmes [...] initial teacher education is already of a good and appropriate standard [...] Most important, the quality of teacher educators is high [...] a well organised, effective and professionally and 
academically sound structure for initial teacher education already exists (Coolahan, 2007, p. 6-7, citing 1991 OECD).

The OECD Report advocated investment in the continuum of teacher education, supporting the " 3 Is" perspective - good quality initial teacher education, followed by a structured form of induction and greatly expanded inservice teacher education. This report repositioned teaching as a complex profession and affirmed the government's prioritization of education as a "strategic force for the social, economic and cultural development of the state" (Coolahan, 2003, p. vi). The report became the springboard for a decade of policy development and legislation formation. The Green (policy proposal) Paper Education for a Changing World was published in 1992, followed by a highly consultative process, and generating a thousand written submissions. In order to distill and analyse these submissions, the National Education Convention (NEC) was convened; this two-week convention served to raise the public's awareness of the issues involved and demonstrated a "partnership approach to education policymaking" (Gleeson, 2004, p. 50). In her foreword to the White Paper, Charting our Education Future (1995), the minister acknowledged the contribution of this consultation process:

[...] for the first time [there was] structured multi-lateral dialogue among all the major partners in education on crucial issues affecting the development of education. They contributed substantively to enhanced mutual understanding and, I hope, have facilitated a more robust consensus in support of key changes (1995, p. 1).

The Report of the National Education Convention became the foundation document for the White Paper, and the number of references to and direct quotations from the NEC is notable. The White Paper reaffirmed the teaching career, "as a continuum, involving initial teacher education, induction processes and in-career development opportunities, available periodically throughout a teacher's career" (NEC, p. 85, cited in the White Paper, p. 128). This was further endorsed by reference to the OECD Review (1991) which identified the challenges facing the teaching profession in Ireland as, "how to address in a comprehensive way the needs and aspirations of talented and well-educated young teachers [...] as they progress through their careers" (OECD, 1991, p. 98, cited in White Paper, p. 135).

The White Paper also reiterated the call made by the NEC for the establishment of a Teaching Council, that would "give the teaching profession a degree of control over and responsibility for its own profession and allow for 
its closer engagement in the process of change" as well as acting as the agent for implementing the European Union directive in relation to the "mutual recognition of teacher training qualifications" (p. 146). Throughout, the White Paper recognized that "Ireland's development is now linked in an integral way with the development of Europe. This poses no threat to our national identity. Rather it offers significant opportunities for growth and development” (p. 215) and committed that, "Ireland will continue to contribute fully to education initiatives within the European Union" (p. 216). The White Paper directly influenced curricular reform for all stages of the school system as well as spawning a raft of major educational legislation including the Universities Act (1997), the Education Act (1998), the Education (Welfare) Act (2000), the Equal Status Act (2000-2004), the National Qualifications Authority Act (2001), the Teaching Council Act (2001), and the Education for Persons with Special Education Needs Act (2004). It is evident that while the White Paper and subsequent legislation was solidly rooted in the work of both the National Education Convention, it was also cognisant of the pragmatic and strategic importance of the international landscape. In parallel with the policy drive of the 1990s, some actions were taken which demonstrated a commitment to policy change. These included the establishment of the In-Career Development Unit (1992) within the Department of Education to provide co-ordination and direction in relation to in-service education. When preparing for the National Development Plan (1993), the government successfully secured $£ 45$ million in EU funding under the Human Resources Operational Program and the European Regional Development Fund to support inservice education and to develop the network of teacher centres, both of which were essential to the roll-out of revized curricula at primary and post-primary level (Egan, 2004, p. 12; Coolahan, 2007, p. 10).

\section{Policy drift}

While the minister was clear that the White Paper represented "a comprehensive agenda for change and development" (1995, p. 1), no explicit plan for educational change was developed. Critical of the capacity of the Department of Education to be a key policy actor, O'Sullivan described the process of policy development as "pragmatic gradualism", where things move forward "on a gradual path, testing responses, slowing down or speeding up as circumstances permit" (O'Sullivan, 2005, p. 175, citing Coolahan, 1989). Given the level of engagement of policy makers in education review and debate during the 1990s, expectations of the teacher educators for change were heightened: "the stage was now set for early direct action to implement these key dimensions of 
government policy on teacher education. However, this was not the case and the impressive momentum which had built up [...] lost its urgency, and, what might be termed, a period of policy drift set in" (Coolahan, 2007, p. 16).

Action was deferred, and instead, two reviews of initial teacher education were commissioned (Byrne, 2002; Kellaghan, 2002). Speaking in 2004, Dr Kellaghan, Chair of the primary teacher education review group observed that the rapid rate of change in Irish society presented serious challenges for the education system, which had obvious implications for teacher education; "The Group realised at an early stage that its deliberations might result in a call not for minor adjustments, but for a root and branch reform based on a reconceptualization of teacher education" (Kelleghan, 2004, p. 20). However, the Kellaghan Report was met with an official silence and two years later it was not clear to the Chair if the report's basic tenets, or any of its 61 recommendations, had been accepted by the Department (2004, p. 26). A similar delay was evident in the establishment of the Teaching Council: although legislation was enacted in 2001, the Council was launched in spring 2005 and not formally established on 1 March 2006, eleven years after the government's decision to establish the Council was announced in the White Paper.

The capacity of the Department of Education to make and implement policy decisions was the subject of criticism in the Review of the Department's Operations, completed in 200o. In his conclusions, Cromien, the former Secretary in the Department of Finance, recognized that policy development was haphazard:

This lack of clarity in policy formulation leads to educational policy often being determined elsewhere, for example, through negotiations with interest groups or under national agreements or, indeed, in the courts, through criticism of the lack of adequate provision for e.g. children and young people with special needs. This in turn has led to a certain passivity in the Department in relation to new developments (2000, p. 4).

Referring to this lack of progress, the Minister for Education, Ruairí Quinn noted, "A remarkable policy agenda had been nurtured and developed through the 1990 o [...] But the impetus for reform faltered and what was missing in the past decade was the political will and vision to champion change" (2012).

Teacher education was not moribund during this time; the number of providers and programmes proliferated; by 2012, there were 19 publicly funded providers of teacher education (Hyland, 2012). Programme renewal was underway as the impact of reports, recommendations and directives from an increasingly powerful and integrated European Union were being felt on 
campuses; arising from the Bologna Declaration (1999) all third-level institutes were required to present their programmes in terms of learning outcomes and to adopt the European Credit Transfer System (ECTS), to ensure comparability of awards across Europe. Teacher educators were part of the TUNING project (2001-2008) (Drudy, 2004, pp. 35-36), and Ireland was the leading country (of 48 higher education systems) in terms of the implementation of the Bologna goals and objectives (Gleeson, 2013, p. 923). While individual teacher education institutions updated and reviewed the quality of their teacher education programmes, adjusted them to incorporate reflective practice, action research and technological advances, there had been no widespread review of the structure of teacher education. Curriculum overload was a concern, and educationists were aware of the urgent need to extend the duration programmes (Harford, 2008, p. 90).

One of the few teacher education developments of the first decade of the $21^{\text {st }}$ century was the recognition by the Department of Education and Science (DES) in 2003 of a blended learning, part-time programme for primary teacher education offered by a private for-profit agency, Hibernia College. This was "an unexpected development in teacher education" (Coolahan, 2007, p. 22) and while the numbers of students undertaking teacher education programmes in state supported colleges are capped by the DES, no cap is applied to this private provider. As a consequence, Hibernia College has become the dominant route for graduate entry to primary teaching; in 2011, of 914 graduate candidates qualifying as teachers 713 (78\%) came from Hibernia College, representing almost $38 \%$ of all primary level teachers qualifying in that year (Hyland, 2012, p. 12). During the period 2007-2011, Hibernia College qualified 2585 teachers, and the College has now expanded to provide teacher education for the post-primary sector. Anticipating the current over-supply of teachers, Harford described it as "one of the most troubling developments to emerge in recent years" (2008, p. 89).

\section{Teachers Matter: Attracting Developing and Retaining Teachers, OECD, 2005}

Ireland was one of twenty-five countries participating in Teachers Matter, which was launched in 2002 and, in the absence of any advancement in teacher education policy, the foreword to Country Background Report (2003) underlines the contribution of the OECD as a stimulus to progress: "the great value of this OECD research project is the stimulation it provides to diagnose and reflect on these [problems] from a policy perspective, enriched by some best practice procedures from international experience" (Coolahan, 2003, p. 
vii). Ireland took a leading role in this review and hosted a meeting of the OECD Education Ministers in Dublin in 2004, chaired by then Irish Minister for Education, Noel Dempsey. The summary of this meeting was the foundation document for the final report of Teachers Matter, which served to highlight the centrality of teacher policy on national agendas and to chart the route by which Education Ministers could achieve the agreed goal of raising the quality of learning for all. The report identifies the pivotal role the teaching profession must take in this process, and within this context, the forthcoming Teaching Council in Ireland was cited as an exemplar of good practice in "profession-led standard setting and quality assurance in teacher education, teacher induction, teacher performance and career development" (OECD, 2005, p. 216). At the launch of Teachers Matter (2005), the then Minister for Education and Science, used the platform to query the quality and relevance of initial teacher education programmes for primary teachers:

I would question whether the range of content covered on pre-service programmes has adequately kept pace with the changing demands that now face teachers[...] I have concerns that the focus of provision has shifted too far towards academic studies at the expense of core teaching methodologies, teaching practice and the wider educational science skills (Hanafin, 2005, pp. 3-5).

Teachers Matter was complemented by the EU publication Common European Principles for Teacher Competence and Qualifications (2005), both setting a clear policy direction for the newly established Teaching Council. Expectations for the Teaching Council were high and teacher educators welcomed the collaborative and professional approach of the Council (Nic Craith, 2014). The Council established a consistent and incremental work rate publishing the Codes of Professional Conduct for Teachers (2007), Teaching Council [Registration] Regulations (2009), Initial Teacher Education: Criteria and Guidelines for Programme Providers, (2011a), Initial Teacher Education: Strategy for the review and professional accreditation of existing programmes (2011b.), Draft code of professional conduct for teachers, $2^{\text {nd }}$ ed. (2011c) and Code of professional conduct for teachers (2012). Eight teacher education providers volunteered to pilot programme reviews and in 2010 completed detailed pro forma, in addition to submitting extensive supplementary documentation, in advance of an accreditation visit. Teacher educators engaged in this process in a positive and constructive manner, despite concerns of that this process was evidence of creeping managerialism and compliance- and results- driven accountability (Conway \& Murphy, 2013). 


\section{PISA - global benchmarking an opportunity for radical reform}

Through its statistics, reports and studies, the OECD has achieved "a brand which is regarded as indisputable" and its policy recommendations are accepted as valid by politicians and scholars alike (Grek, 2009, p. 25). The introduction by the OECD of the Programme of International Student Assessment (PISA) created international benchmarks that allow for the global comparison of education performance and achievement of 15-year olds, across a range of subjects. PISA has "radically changed the geography of education since it was first introduced in 2000" (Sahlberg, 2011, p. 119) and Grek has asserted that "no other empirical study managed to stir up the educational policy landscape in Germany in the way that PISA 2000 did; the "PISA-shock" has had major impact not only on policy-making, but most crucially on the public consciousness" (Grek, 2009, p. 30, citing Pongratz, 2006).

While Ireland's strong performance in PISA 2000 and 2003 was perceived to affirm the high quality of the education system, "the results of the OECD's PISA 2009 tests were a shock for the Irish educational system. The decline in the reading and mathematics scores of students in Ireland compared to previous PISA tests was unexpected" and the Chief Inspector described as "sobering [...] the fact that PISA suggests that $17 \%$ of all fifteen years olds and almost one in four teenage boys lack the literacy skills to function effectively in today's society" (Hislop, 2011, p. 18). Ireland's PISA performance attracted negative media attention and questioned assumptions about the quality of education in our schools; Cosgrove and Cartright (2014) examined the reporting of PISA results in the Irish media citing one headline that stated, "Shattering the myth of a world-class education system" (Irish Times, December 8, 2010), while a web-based forum Education Matters described the results as "an urgent call to action" (December 14, 2010). The government responded by publishing a draft literacy and numeracy strategy in November 2010, which generated 480 detailed written submissions and 60 oral presentations (Hislop, 2011). The revised literacy and numeracy strategy, Literacy and Numeracy for Learning and for Life was published in July 2011. Embedded within this document was the most complete policy on teacher education issued since the White Paper of 1995; spanning just four pages, the policy restated its commitment to the continuum of teacher education and affirmed the "sound basis" provided by the Teaching Council to implement the required developments (p. 33). The thrust of the policy was distilled into a short pull-out message in the margin: "We have to improve the quality and relevance of initial teacher education" (p. 32). The 
policy statement was followed by a detailed action plan to "improve teachers' skills in the teaching, learning and assessment of literacy and numeracy". This action plan included the "dramatic" announcement (Coolahan, 2013, p. 20) that the BEd programme (primary teachers) would be extended in duration to four years and reconfigured to replace the "academic elective" with programmes more closely related to education; this revised programme was to be offered to new entrants in 2012-13. Similarly, the graduate programmes for primary and post-primary teacher education were to be extended to two years for new entrants in 2014-15. The overall content of ITE programmes was specified to include an emphasis on literacy and numeracy, with enhanced provision ICT, special education, and assessment; in addition, the plan included directions on the duration and nature of school placement within the programmes. The policy was far more direct, focused and specific than experienced heretofore. While the extension of programmes was a much-awaited decision (Coolahan, 2013), the implementation date followed by the subsequent publication of Initial Teacher Education Criteria and Guidelines for Programme Providers (August 2011) and the Strategy for the Review and Professional Accreditation of Existing Programmes (September 2011), created a stressful timeframe for those involved in the reconceptualization of the concurrent BEd for primary level teachers. This intensive and unnecessarily rushed process was undertaken at a time when teacher education institutions were experiencing harsh austerity measures, which included significant year-on-year budget cuts and reductions in staffing. Speaking in 2011 the Chief Inspector, Harold Hislop, described the PISA results as an opportunity to introduce long-desired reform of the system:

In 2010, we had a unique opportunity to galvanise the political and educational systems and the wider public into tackling long-standing issues and challenges in Irish education. The formulation of the Literacy and Numeracy Strategy was designed to harness this energy for the longterm improvement of the educational system (p. 18).

It is evident that the PISA (2009) results were utilized as a springboard for and justification of radical change in teacher education; at a time of deepening economic crisis and under the "leadership of a reform-oriented Minister of Education", Conway and Murphy (2013) describe this as the "perfect storm", which has met the "rising tide of accountability" in higher education.

The reform of the content of initial teacher education was closely followed by a review of the associated institutional structures. In line with the Higher Education Authority's (HEA) strategy for the consolidation of higher education institutions and enhanced collaboration and coherence between 
institutions, the Minister asked the HEA to "engage with the initial teacher education sector so as to identify possible new structures for teacher education based on a reconfiguration of existing provision [...] to envision innovative strategies so that Ireland can provide a teacher education regime that is comparable with the world's best" (Hyland, 2012). An international panel was established to review the structures of ITE and, while recognising the central role played by teacher education to "sustainable economic growth and prosperity" (Sahlberg, 2012, p. 6), the panel recommended that two teacher education providers be closed and that the remaining providers be consolidated into six clusters, thereby creating critical mass (Sahlberg et al., 2012). While one provider, Froebel College, had previously agreed to merge with and transfer to the NUI Maynooth campus in advance of this review, the Panel's report became the stimulus for other providers such as DCU, St Patrick's Drumcondra, Mater Dei and Church of Ireland College, to merge to form one institute of education. The recommendations of the Sahlberg report, underpinned by comparative education research and PISA data, have been accepted by the educational community at all levels without opposition or controversy. The infrastructure of teacher education is in transition, and while the ultimate shape of provision is far from clear, one of the by-products of this process is to diminish the denominational provision of teacher education. While this was never articulated as a desired outcome of the process, it would seem that this policy decision will dramatically alter the landscape of teacher education and significantly reduce church governance in its provision.

\section{Conclusion}

Irish education experienced "policy insulation" (O’Sullivan, 2005, p. 178) for the first half of the nineteenth century; its first exposure to international policy development was through the Investment in Education survey, which served to inextricably link education policy with economic development. The Hargreaves and Goodson framework of change over time (2006), provides a useful tool to review change in Irish education; it is evident that engagement with the OECD in the 1960s reflected the age of "optimism and innovation" that concentrated on economic growth and individual emancipation (Sahlberg, 2006, p. 260). Irish education experienced a new child-centred curriculum at primary level, universal access to free second-level education and the introduction of an all-graduate teaching profession. The period of 1990 s was loosely aligned to the second age of "complexity and contradiction" where the establishment of legislation to govern Irish schools and schooling marked an 
increased role for the state in the control of education, and diversity in schools created demands for greater inclusivity, with an emphasis on learning for all. The third phase, the age of "standardization and marketization", where datadriven decision-making, experienced in other cultures and contexts in the late 1990s-early 2000 period, characterizes much of the policy development post 2009. While Irish policy has reflected loosely international developments, the rate and intensity of the adoption of international policy has differed significantly. In recent decades, the OECD has become one of the most powerful agents of transnational education governance. Its influence elides national boundaries and has contributed to the emergence of a "global education policy field" (Grek, 2009, p. 28). While nations are located in a web of policy relations that exert influence on national policy, Grek asserts they are not powerless in this process. Writing on the balance between the national and international policies within teacher education, Musset has outlined:

The design of the teacher education has to respond to specific needs of each system [...] take into account that the way in which practising teachers learn depends on many factors - country's past traditions, existing institutions, way the educational system articulates as a system. Teacher education models are influenced by the character and the status of the teaching profession [...] must be context-specific (Musset, 2010, p. 45).

While acknowledging the role of the OECD in "the seeding and orientation of education policy in Ireland for more than 40 years" (Galvin, 2009, p. 276), through extensive consultation and extended periods of gestation, international reviews and trends were mediated through an internal lens, to create national policy. The period following the 1991 OECD Review was a clear example of how external policy produced considerable national debate and discussion, resulting in an agreed trajectory tailored for Irish education, which formed the bedrock for policy development.

The drift between policy and action created a surge in legislation development with little implementation, and again the impetus for change was provided by Teachers Matter (2005). On this occasion, the external review provided the context for the establishment of the Teaching Council, which has become a significant internal policy actor within teacher education. Building on the policies in relation to the teaching continuum that had been in development for almost two decades, the Teaching Council began a process of consultation and incremental change, creating the documentary infrastructure and processes to implement policy. The Council consulted widely with the teaching profession 
in the development of the Code of Professional Practice and the Code of Professional Conduct, and while in line with international practices, these documents articulate the Council's "standards", reflecting the cultural values and traditions of the Irish teaching profession. Although Teachers Matter affirmed the policy of the continuum of teacher education and advised on a path of action, the Department of Education and Skills (DES) again engaged in the tactic of diplomatic inactivity; on this occasion, this period allowed for the renewal and reconfiguration of the Department, where a newfound confidence and sense of agency became evident. Following the publication of the PISA (2009) results, the DES was ready to make comprehensive reform statements; the PISA results were not just a spur for change, but were utilized as a justification for radical reform. Under the political stewardship of an ambitious Minister for Education and led by a strong Department management team (Chief Inspector, Director of Education and Secretary General), clear policy decisions were made and a tight implementation plan was published. The Minister announced the reform of the content and duration of initial teacher education, the level of reform is monitored and assessed by the Teaching Council through accreditation procedures, and the HEA is now consolidating the number of teacher education providers.

Throughout the last four decades, EU policy and in particular OECD reports, have played a significant role in creating the context for change, stimulating internal debate and providing a foundation for national policy development. Carroll and Kellow (2011, p. 34) state "the key to the effectiveness of peer reviews lies not in any coercive sanction for non-compliance, but, rather, their hortatory nature" (cited by Sellar \& Lingard, 2013, p. 712). Irish policy makers have depended significantly on external reviews and international guidance to spur policy development and reform. Working within an historical context where church provision of education and teacher education seemed incontrovertible, the repeated intervention of the OECD in its reviews and latterly in its benchmarking of educational systems, has served to justify and validate policy development. While previous administrations did not have the vision or ambition for change, the momentum for change has been growing and since 2011 teacher education has been the focus of unprecedented reform. While evidence of the "perfect storm" has been discussed by others (Conway, 2013), the reliance by successive Irish governments on OECD reports and the unquestionable status attained by PISA, contributed in no small way to the wave of reform currently experienced by teacher education in Ireland. 


\section{References}

Byrne, K. R. (2002). Advisory group on post-primary teacher education. Dublin: Department of Education and Science.

Cromien, S. (2000). Department of Education and Science: Review of Department's operations, systems and staffing needs report. Dublin: Department of Education and Skills.

Conway, P. F. (2013). Cultural Flashpoint: The politics of teacher education reform in Ireland. The

Educational Forum, 77(1), 51-72.

Conway, P. F., \& Murphy, R. (2013). A rising tide meets a perfect storm: New accountabilities in teaching and teacher education in Ireland. Irish Educational Studies, 32(1), 11-36.

Coolahan, J. (1981). Irish Education; Its History and Structure. Dublin: Institute of Public

Administration.

Coolahan, J. (2001).Teacher education in Ireland and Western Europe: a comparative analysis. Irish

Educational Studies, 20(1), 335-368.

Coolahan, J. (2003). Attracting, Developing and Retaining Effective Teachers: Country Background Report for Ireland. Dublin: Department of Education and Science

Coolahan, J. (2004). The Historical Development of Teacher Education in the Republic of Ireland. In

A. Burke (Ed.), Teacher Education in the Republic of Ireland: Retrospect and Prospect. Armagh: Centre for Cross-Border Studies.

Coolahan, J. (2007). A Review Paper on Thinking and Policies Relating to Teacher Education in Ireland.

Paper prepared for the Teaching Council, Ireland. Retrieved from www.theteachingcouncil.ie Coolahan, J. (2011a). Policy on the Continuum of Teacher Education - from Vision to Reality (?).

Address given to Teaching Council Conference, A Vision for the Continuum of Teacher Education,

Cork, 11 November.

Coolahan, J. (2011b). Address at the launch of the Forum on Patronage and Pluralism. Retrieved from http://www.education.ie/en/Press-Events/Speeches/2011-Speeches/SP11-04-19A.html\#sthash. QubBnxoX.dpuf

Coolahan, J. (2013). Towards a new era for teacher education and the engagement of the teaching profession. Irish Teachers' Journal, 1(1), 9-27.

Cosgrove, J, \& Cartwright, F. (2014). Changes in achievement on PISA: the case of Ireland and implications for international assessment practice. Large-scale Assessments in Education, 2(2).

Drudy, S. (2006). Change and Reform in Teacher Education in Ireland: a Case Study in the Reform of Higher Education. Seminar on Modernization of Study Programmes in Teachers' Education in an International Context. Ljubljana, 23 February 2006.

Egan, E. (2004). Continuing professional development of teachers. In A. Burke (Ed.), Teacher Education in the Republic of Ireland: Retrospect and Prospect (pp. 11-18). Armagh: Centre for CrossBorder Studies.

Farrell, B. (Ed.) (1998). Issues in Education: Changing Education, Changing Society. Dublin: ASTI.

Galvin, C. (2009). Public Policy Making: The emerging policy making modality and its challenge for 
education policy research in Ireland. In S. Drudy (Ed.), Education in Ireland, Challenge and Change.

Dublin: Gill \& Macmillan.

Gleeson, J. (2004). Concurrent Teacher Education (Post-primary) in the Republic of Ireland: Some Issues and Trends. In A. Burke (Ed.), Teacher Education in the Republic of Ireland: Retrospect and Prospect. Armagh: Centre for Cross-Border Studies.

Gleeson, J. (2013). The European Credit Transfer System and curriculum design: product before process? Studies in Higher Education, 38(6), 921-938.

Government of Ireland. (1992). Education for a Changing World: Green Paper on Education. Dublin: the Stationery Office.

Government of Ireland. (1995). Charting Our Education Future: White Paper on Education. Dublin: the Stationery Office.

Grek, S. (2009). Governing by numbers: the PISA 'effect' in Europe. Journal of Education Policy, 24(1), 23-37.

Hanafin, M. (2005). Speech on the occasion of the launch of the OECD Report Teachers Matter. 27 May. Retrieved from www.education.ie.

Harford, J. (2008). Ireland. In T. O’Donnoghue \& C. Whitehead (Eds.), Teacher education in the English-speaking world: Past, present and future (pp. 75-91). Charlotte, NC: Information Age Publishing.

Harford, J. (2009). The emergence of a national policy on teacher education in Ireland. Journal of Educational Administration and History, 41(1), 45-56

Harford, J. (2010). Teacher education policy in Ireland and the challenges of the twenty-first century. European Journal of Teacher Education, 33(4), 349-360.

Hargreaves, A., \& Goodson, I. (2006). Educational Change over Time? The sustainability and non-sustainability of three decades of secondary school change and continuity. Educational Administration Quarterly, 42(1), 3-41.

Hislop, H. (2011). Teacher education and Ireland's national strategy to improve literacy and numeracy. Speech given at SCoTENS Annual Conference, Radisson Blu Farnham Estate, Cavan, 29 September 2011. Retrieved 27. 6. 2014 from http://scotens.org/docs/2011-Hislop-speech.pdf Hyland, A. (2012). A Review of the Structure of Initial Teacher Education Provision in Ireland: Background Paper for the International Review Team, May 2012. Dublin: Department of Education and Skills.

Hyland, A., \& Milne, K. (1987). Irish Educational Documents, Vol.1. Dublin: CICE.

Kellaghan, T. (2002). Preparing Teachers for the 21st Century: Report of the working group on primary preservice teacher education. Dublin: Stationery Office.

Kelleghan, T. (2004) Preparing teachers for the $21^{\text {st }}$ Century: Report of the Working Group on Primary Preservice Teacher Education. In A. Burke (Ed.), Teacher Education in the Republic of Ireland: Retrospect and Prospect. Armagh: Centre for Cross-Border Studies.

Limond, D. (2010). [An] historic culture ... rapidly, universally, and thoroughly restored? British influence on Irish education since 1922. Comparative Education, 46(4), 449-462. 
Loxley, A., Seery, A., \& Walsh, J. (2014). Investment in Education and the tests of time. Irish Educational Studies, 33(2), 173-193.

Musset, P. (2010). Initial Teacher Education and Continuing Training Policies in a Comparative Perspective: Current Practices in OECD Countries and a Literature Review on Potential Effects. OECD Education Working Papers, No. 48, OECD Publishing. Retrieved from http://dx.doi. org/10.1787/5kmbphh7s47h-en

Organisation for Economic Co-operation and Development. (1991). Review of National Policies for Education: Ireland. Paris: OECD.

Organisation for Economic Co-operation and Development. (2005). Teachers Matter: Attracting, Developing and Retaining Effective Teachers. Paris: OECD.

Organisation for Economic Co-operation and Development. (2008). Education Policy Analysis. Paris: OECD.

Organisation for Economic Co-operation and Development. (2009). PISA 2009 Results: What students know and can do: Student performance reading, mathematics and science. Vol. 1. Paris:

OECD. Retrieved from http://www.oecd.org/pisa/pisaproducts/pisa2oo9

O'Connor, M. (2014). Investment in edification: reflections on Irish education policy since independence. Irish Educational Studies, 33(2), 193-213.

O’Donoghue, T. (2006). Bilingual education in pre-independent Irish-speaking Ireland 1800-1922: A history. New York: Edwin Mellen Press.

O’Donoghue, T., \& Harford, J. (2012) Contesting the Limond thesis on British influence in Irish education since 1922: a comparative perspective. Comparative Education, 48(3), 337-346.

O'Sullivan, D. (2005). Cultural Politics and Irish Education since the 1950s: Policy paradigms and power. Dublin: IPA.

Quinn, R. (2012). The future development of education in Ireland. Studies: an Irish Quarterly Review, 101(402, Summer 2012), 1-3.

Sahlberg, P. (2006). Education reform for raising economic competitiveness. Journal of Educational

Change, 7, 259-287.

Sahlberg, P., Munn, P., \& Furlong, J. (2012). Report of the International Review Panel on the structure of initial teacher education provision in Ireland: Review conducted on behalf of the Department of Education and Skills. Dublin: Department of Education and Skills.

Sellar, S., \& Lingard, B. (2013). The OECD and global governance in education. Journal of Education Policy, 28(5), 710-725.

Teaching Council. (2007). Codes of professional conduct for teachers. Maynooth: Teaching Council. Teaching Council. (2011a). Initial teacher education: Criteria and guidelines for programme providers. Maynooth: Teaching Council.

Teaching Council. (2011b). Initial teacher education: Strategy for the review and professional accreditation of existing programmes. Maynooth: Teaching Council.

Teaching Council. (2011c). Draft code of professional conduct for teachers. $2^{\text {nd }}$ edition. Maynooth: Teaching Council. 
Walsh, J., McCoy, S., Seery, A., \& Conway, P. (2014). Investment in Education and the intractability of inequality: Editorial. Irish Educational Studies, 33(2), 119-123.

\section{Biographical note}

Teresa O'DoherTy, dr., is Dean of Education at Mary Immaculate College, Limerick. She is a member of a wide range of academic and professional committees; she is a member and former Southern Co-Chair of The Standing Conference on Teacher Education, North and South (SCoTENS), an invited member of the NCCA Early Childhood and Primary Education Committee, as well as being the invited Chair of the International Panel of Judges, Teacher Education Section of the Undergraduate Awards 2012-2014. Her personal research interests are in the History of Irish Education. 